\title{
DEMOGRAPHICS CHARACTERISTICS OF CONSUMERS AS \\ FACTORS IN THE PURCHASE OF CEREAL PRODUCTS IN THE REPUBLIC OF SERBIA
}

\author{
Mina Kovljenić ${ }^{1}$ Saša Raletić-Jotanović ${ }^{2}$,Jelena Nestorov-Bizonj ${ }^{3}$, \\ Radovan Vladisavljević4 ${ }^{4}$ Slobodan Živkucin ${ }^{5}$ \\ *Corresponding author E-mail: mina.sk90@yahoo.com
}

\begin{abstract}
A R T I C LE IN F O
A B S T R A C T

Original Article

Today, there is a trend towards a healthy lifestyle and a healthy

Received: 22 February 2021

diet. Cereals are considered the healthiest food because of

Accepted: 24 May 2021 their properties. They contain a good ratio of carbohydrates, doi:10.5937/ekoPolj2102503K

UDC 336-058:664.696(497.11) unsaturated fatty acids, vitamins, proteins, minerals and plant fibers that are necessary for human nutrition. Therefore, the production and trade of cereals in the world tend to grow

Keywords:

consumer, cereal products, purchase, demographic characteristics, food security

JEL: Q11, Q02, Q18, J10, J31 significantly. The aim of the paper is to identify the demographic characteristics of consumers that influence consumer decision when buying cereal products. The empirical research was conducted on a sample of 201 respondents from the territory of the Republic of Serbia through a questionnaire, which was made for research purposes. Through the discovery of consumer preferences, there is an opportunity to help producers of cereal products in Serbia to offer products that will meet the requirements of consumers.
\end{abstract}

(C) 2021 EA. All rights reserved.

1 Mina Kovljenić, Faculty of Economics in Subotica, University of Novi Sad, Department of Agrarian Economy and Agribusiness, Novi Sad, Republic of Serbia, Phone: +381 6454401 06, E-mail: mina.sk90@yahoo.com, ORCID ID (https://orcid.org/0000-0002-7548-3938)

2 Saša Raletić-Jotanović, Professional College of Management and Business Communication, Novi Sad, Republic of Serbia, E-mail: raletic.sasa84@gmail.com, ORCID ID (https://orcid. org/0000-0002-2181-1852)

3 Jelena Nestorov-Bizonj, Cooperative Union of Vojvodina, Novi Sad, Republic of Serbia, Phone: +381641410570, E-mail: jelenanb@yahoo.com, ORCID ID (https://orcid.org/00000002-8840-9024)

4 Radovan Vladisavljević, Professional College of Management and Business Communication, Novi Sad, Republic of Serbia Phone: +381 6417895 52, E-mail: tmprad@gmail.com, ORCID ID (https://orcid.org/0000-0002-8502-8584)

5 Slobodan Živkucin, Professional College of Management and Business Communication, Novi Sad, Republic of Serbia, Phone: +381 6558282 82, E-mail: slobodanzivkucin@ gmail.com, ORCID ID (https://orcid.org/0000-0001-6642-1041)

http://ea.bg.ac.rs 


\section{Introduction}

Today's trends in food demand are shaped, among other things, by demographic changes and the modern lifestyle of consumers (Raletić, Sudarević, Katić, Kalinić, \& Kalinić, 2016; Raletić, 2017). The most important demographic changes are the aging of the population, urbanization, larger number of smaller households, an increase in the number of working women and a decline in the birth rate. At the same time, there is a trend of a healthy lifestyle and a healthy diet as a consequence of the modern lifestyle of consumers (Mitić \& Gligorijević, 2015: 336). Due to the epidemic of chronic diseases caused by bad eating habits, interest in the effects of nutrients on health has increased in recent years (Sevak et al., 2004: 160). Food insecurity/security is closely linked to the number of undernourishment. Undernourishment is the result of the absence of one or more factors contributing to good nutrition (Kovljenić \& Raletić-Jotanović, 2020). One of the priorities of each country is to improve food production, ensure food security and high quality, as well as draw attention to the importance of a healthy diet, which is an integral part of preserving and improving health and disease prevention (Radosavljević, 2010: 131).

With the development of consumer awareness, there is an increasing demand for the consumption of healthier products, which are of better quality. Cereals are considered the healthiest food due to their properties. They have a good ratio of carbohydrates, unsaturated fatty acids, vitamins, proteins, minerals and plant fibers, all according to natural human needs (Vlahović, 2015: 37-38). Production and trade of cereals in the world they tend to grow significantly. Cereals in the diet should make up about $30 \%$ of the daily energy intake. Worldwide: rice, wheat, corn and millet are important ingredients in the human diet and are responsible the daily subsistence of a billion people. More than $50 \%$ of the world's daily calorie intake is obtained directly from cereals (Sarwar et al., 2013: 34). Cereal production is growing, primarily in order to meet the growing needs of people. The level of consumption is conditioned by the level of production, ie growing conditions, as well as the consumption habits of individual countries. Failure of grain production due to adverse weather conditions, pathogens or human actions has contributed to increasing grain production in many countries be a key national and international goal (Lafiandra, Riccardi \& Shewry, 2014: 312). 
Figure 1. Overview of global cereal production (tons)

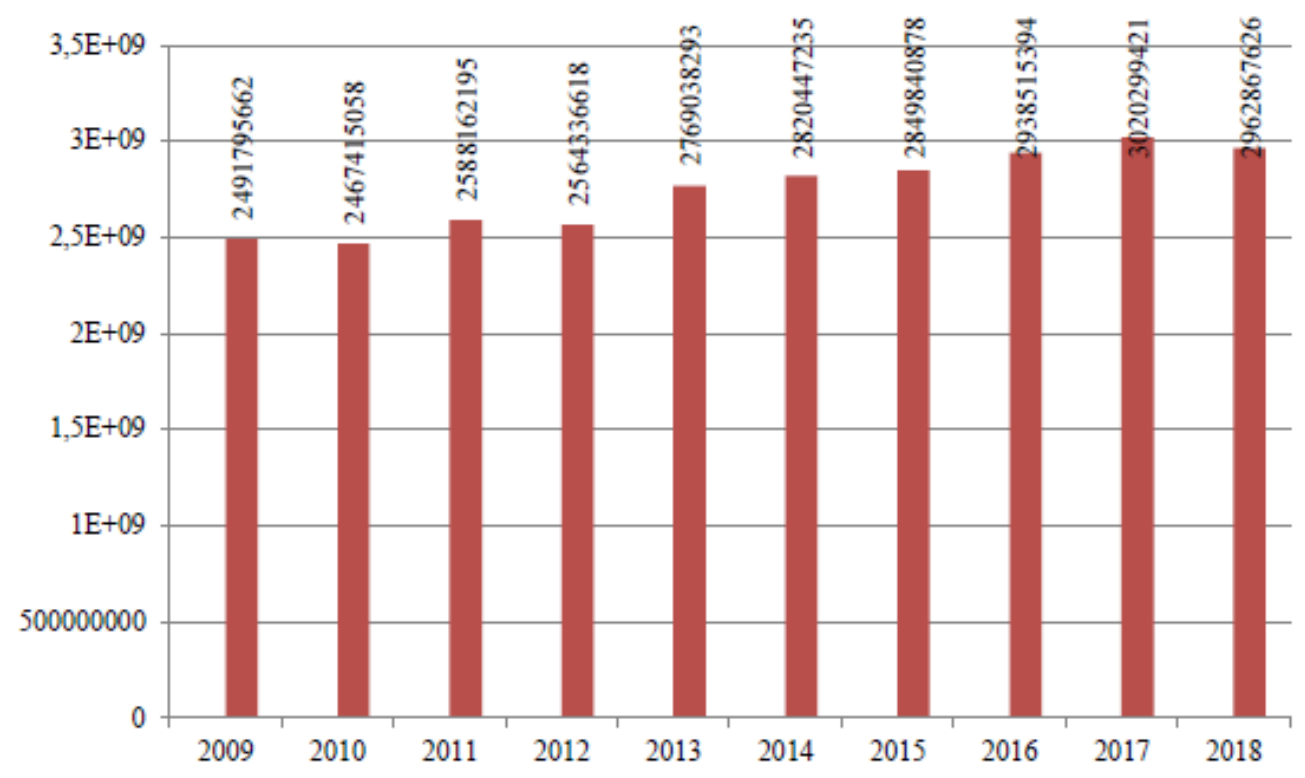

Source: Authors' calculation, based on FAOSTAT data, 2020

Figure 1 shows the global production of cereals from the year 2009 to 2018. Over the years, the production of cereals has more or less oscillated. The lowest production was realized in 2010, while the highest production was recorded in 2017. After 2012, in 2013/2014, 2014/2015, 2015/2016, 2016/2017 the global production of cereals increased significantly (FAOSTAT, 2020). In the world, cereals are grown in over $73 \%$ of the world's total harvested area and contribute with over $60 \%$ of world food production by providing dietary fiber, protein, energy, minerals and vitamins necessary for human health (Charalampopoulos, Wang, Pandiella \& Webb, 2002: 132). Their contribution to the daily diet varies significantly between developing and developed countries. In developing countries, such as Africa and parts of Asia, cereals provide as much as $70 \%$ of the energy value, while in developed countries, such as the United Kingdom, cereals provide about $30 \%$ of energy intake and 50\% of available carbohydrates (Alexandratos, 2006).

In the Republic of Serbia, the largest area of agricultural land belongs to the production of cereals. In the total value of agricultural production in 2019, plant production participated with $66.0 \%$, and livestock with $34.0 \%$. Compared to 2018 , the net index of physical volume of agricultural production decreased by $1.2 \%$. Crop production was $1.9 \%$ higher than in the previous year. Realized production in 2019 year, compared to 2018, was lower in wheat by $13.8 \%$, sunflower by $0.6 \%$, and sugar beet by $0.9 \%$, and higher in corn by $5.5 \%$ (Statistical Office of the Republic of Serbia, 2020). Cereal production in Serbia is one of the largest components of agricultural production. Agricultural production in Serbia can have greater economic effects than now, which is why the factors and demographic characteristics that increase the purchase of cereals should be investigated, which is the 
goal of the paper. Consumer choice of products is influenced by many related factors. Demand for consumer goods is conditioned by economic, demographic, socio-cultural, geographical, sociological and psychological factors (Mayer, 1978). Bearing in mind the importance of cereals in human nutrition, identifying factors that influence the purchase of cereal products is essential in maintaining food security.

The aim of this paper is to identify the key demographic characteristics of consumers that influence their decision when buying cereal products. The analyzed demographic characteristics of consumers are: gender, level of education, financial situation and monthly income, which will be explained in more detail below.

By revealing the demographic characteristics of consumers, there is an opportunity to help producers of cereal products in Serbia to offer products that will meet consumer demands, increase the competitiveness of the Serbian economy and maintaining food security, since the world grain production and trade tend to grow significantly.

\section{Demographic characteristics of consumers as factors of purchase of cereal products}

Individual consumption of food and cereals and purchasing decisions are explained by various factors. The factors include the characteristics of individuals and households, information processing capacities and attitudes towards health (EUFIC, 2005).

The demand for consumer goods according to Mayer is conditioned by (Mayer, 1978: 151-167):

1) demographic factors, age, health, household size, their structure;

2) economic factors which include income, price and creditworthiness of the household;

3) socio-cultural factors (level of education of household members);

4) geographical factors that come to the fore through the characteristics of the region where the households are located;

5) sociological and psychological factors (individual differences in taste, attitude towards shopping, etc.);

6) the influence of complementary or substitution products.

Sanlier and Karakus indicated two groups of factors that influence the consumer's choice of food and cereals (Sanlier \& Karakus, 2010: 141):

1) factors related to consumers, which include: attitude towards health and healthy lifestyle, sensory variables, social relations, knowledge of food and eating habits, lifestyle, age, gender, education; and

2) marketing factors that include primarily the price, distribution and marketing communications of food products. 
One of the approaches in studying food choices comes from socio-psychological research of behavior. In this approach, it is assumed that many influences on food choices come from the beliefs and attitudes of the individual. Beliefs about nutritional quality and the effects of food on health may be more important than the actual nutritional qualities and health consequences when choosing an individual. Also as stated by Shepherd (Shepherd, 1999: 808):

1) demographic,

2) marketing,

3) economic,

4) social,

5) cultural or

6) religious factors can affect the attitudes and beliefs of an individual.

Empirical studies have shown that demographic factors such as gender, age, education, and individual income play an important role in determining food consumption patterns worldwide (Roux et al., 2000; Roslow et al., 2000; Ali, Kapoor \& Moorthy, 2010).

Certain studies have shown that women have a greater tendency to buy products with health declarations (De Jong, Ocke, Branderhorst \& Friele, 2003: 275), while other studies have found no evidence of gender differences (Urala \& Lahteenmaki, 2007: 1).

Other studies have found that with increasing age, health concerns increase, as does the preference for products with health declarations (Ares, Gimenez, \& Gambaro, 2008; Simon and Manohar, 2012). However, there is evidence to support the idea that the younger population also prefers products with health declarations as well as older age groups (Lahteenmaki, 2013: 198).

There is a positive relationship between income and food choices. The amount of income also affects the purchase of cereal products. The more affordable cereal products become, the more households will buy them (Simon \& Manohar, 2012: 1-3). Kaur and Singh investigated the factors that lead to the purchase of cereal products and their research results showed that external influences, health, brand awareness and quality are the main factors influencing the purchase of cereal products (Kaur \& Singh, 2014: 47). The results of research by Kamalaveni and Nirmala (2000) showed that age, occupation, education, family size and annual income have a proportional impact on per capita food costs (Kamalaveni \& Nirmala, 2000: 12-18). The results of a study conducted by Worsely (2003) showed that consumers who consume white bread are younger, less educated, have children or are smokers (Worsely, 2003: 695). Research conducted by Binkley and Eales has shown grain prices, demographic variables, and the knowledge about the health elements of cereals positively affect the consumer's choice (Binkley \& Eales, 2000). Ares and Gambaro indicated that demographic characteristics such as age and gender are key determinants that influence the acceptance of functional food by consumers (Ares \& Gambaro, 2007). 
Income growth leads to a change in consumption, primarily to a more varied diet that includes a higher proportion of animal proteins, fats and oils (Valin et al., 2014: 52). While on the other hand with income growth, there is a decrease in demand for cereals, fruits and vegetables (Herforth \& Ahmed, 2015: 505-520).

Due to all the above, we start from the assumptions:

(H1): The gender of consumers affects the purchase of cereal products in the Republic of Serbia.

(H2): The level of consumer education affects the purchase of cereal products in the Republic of Serbia.

(H3): The financial situation of consumers affects the purchase of cereal products in the Republic of Serbia.

(H4): Monthly incomes of consumers affect the purchase of cereal products in the Republic of Serbia.

\section{Research methodology}

\section{Sample}

The research was conducted on the territory of the Republic of Serbia in 2020, and 201 respondents participated in it. The sample is considered representative considering: the size of the sample in relation to the basic set, the nature of the research, the number of variables to be researched and the desired level of belief.

Table 1. Sample characteristics

\begin{tabular}{|l|l|}
\hline Gender of respondents & Number of respondents \\
\hline Male & 98 \\
\hline Female & 103 \\
\hline Age of respondents & Number of respondents \\
\hline up to 20 years & 14 \\
\hline od 21-30 & 98 \\
\hline od 31-40 & 49 \\
\hline od 41-50 & 16 \\
\hline over 50 years & 24 \\
\hline Place of residence & Number of respondents \\
\hline urban settlement & 112 \\
\hline suburb & 58 \\
\hline rural area & 31 \\
\hline Degree of education & Number of respondents \\
\hline completed primary school & 8 \\
\hline completed high school & 72 \\
\hline completed college & 99 \\
\hline master or doctor of science & 22 \\
\hline Financial situation & Number of respondents \\
\hline without income (pupil, student, unemployed) & 61 \\
\hline
\end{tabular}




\begin{tabular}{|l|l|}
\hline with income (employee, pensioner) & 140 \\
\hline Income & Number of respondents \\
\hline less than 25.000 RSD & 22 \\
\hline od 25.001 do 50.000 RSD & 61 \\
\hline od 50.001 do 80.000 RSD & 36 \\
\hline more than 80.000 RSD & 21 \\
\hline
\end{tabular}

Source: Author

The analyzed demographic characteristics of the sample are gender, level of education, financial situation and monthly income of individuals. The study involved 98 males and 103 females. Regarding the level of education of respondents, 8 respondents have completed primary school, 72 respondents have completed high school 99 respondents have completed college or university and 22 respondents have a master's or doctor degree. In the sample, 61 respondents was without income (pupil, student, unemployed) and 140 respondents had income (employed, retired). In the income group, 22 respondents had incomes less than $25.000 \mathrm{RSD}$, the largest number of respondents have incomes from 25.001 to $50.000 \mathrm{RSD}, 61$ respondents had 61.000 dinars, from 50.001 to 80.000 RSD have 36 respondents, while the least number of respondents, 21 of them have incomes higher than 80.000 RSD.

\section{Research instrument}

The research instrument used in the paper was a questionnaire, made for research purposes. The questionnaire was made on the basis of the used literature, previous research and author's assumptions that were reformulated into questions.

The first part of the questionnaire refers to identification questions (gender, age, level of education, place of residence, financial situation and income).

The second part of the questionnaire contains statements regarding the frequency of purchases of cereal products, and the impact of health and nutritional properties on their purchase. Consumers responded to these statements with numbers from 1 to 5 , which expressed the extent to which consumers agree with each statement. The numbers had the following meanings:

1 - I do not agree at all; 2 - I mostly disagree; 3 - unspecified; 4 - I mostly agree; 5-I totally agree

\section{Data processing}

For collecting the primary data, descriptive, ie quantitative method was used. Descriptive statistics and regression analysis were used in the paper. The obtained data were analyzed in the GRETL program for Windows OS.

\section{Research results}

In Table 2, descriptive indicators of the scale items for testing the purchase of cereal products are shown. 
Table 2. Descriptive indicators of the scale for testing the purchase of cereal products (min.1, max.5)

\begin{tabular}{|l|l|l|}
\hline Item & M & SD \\
\hline 1. I often buy cereals and cereal products. & 3.36 & 1.18 \\
\hline 2. I buy white bread and pastries. & 3.39 & 1.29 \\
\hline 3. I buy wholemeal bread and pastries. & 3.30 & 1.33 \\
\hline 4. I buy white rice. & 3.39 & 1.37 \\
\hline 5. I buy wholemeal rice. & 2.61 & 1.43 \\
\hline 6. I buy confectionery products (biscuits, waffles) & 3.36 & 1.33 \\
\hline 7. I buy confectionery products of a well-known brand. & 2.83 & 1.36 \\
\hline 8. When choosing confectionery products, I buy those products that are healthier. & 3.24 & 1.23 \\
\hline
\end{tabular}

Source: Author

In Table 2, the results of descriptive statistics are shown. Approximately the same number of respondents buy white bread and pastries and wholemeal bread and pastries. It can be noticed that the respondents are less focused on the more frequent purchase of these cereal products, while among them the purchase of integral rice (item 5) and the purchase of food products of well-known brands (item 7) stand out.

The results of the regression analysis will be presented in the next part. The dependent variable was the purchase of cereal products, which is expressed in terms of value. The impact of independent variable demographic characteristics (gender, level of education, financial situation and monthly income of individuals) on the dependent variable (purchase of cereal products) is shown in Model 1.

Model 1: Purchase of cereal products

Model 1: OLS, using observations 1-206 $(\mathrm{n}=156)$

Missing or incomplete observations dropped: 50

Dependent variable: PurchaseCereal

\begin{tabular}{|l|c|c|c|c|l|}
\hline & Coefficient & Std. Error & t-ratio & p-value & \\
\hline const & 4.34517 & 0.768449 & 5.6545 & $<0.0001$ & $* * *$ \\
\hline LevelEdu & 0.104021 & 0.158243 & 0.6573 & 0.5120 & \\
\hline Gender & -0.342154 & 0.198232 & -1.7260 & 0.0864 & $*$ \\
\hline FinSit & -0.528131 & 0.307994 & -1.7147 & 0.0884 & $*$ \\
\hline Income & 0.0846164 & 0.121849 & 0.6944 & 0.4885 & \\
\hline
\end{tabular}

${ }^{\wedge}$ PurchaseCereal $=4.35-0.342 *$ Gender $+0.104 *$ LevelEdu $-0.528^{*}$ FinSit + $0.0846 *$ Income
(0.768)
(0.198)
(0.158)
(0.308)

(0.122) 
Based on the results of regression analysis (Model 1), it can be concluded that gender and financial situation, as demographic characteristics, represent significant factors influencing the purchase of cereal products.

Figure 2. Normal distribution

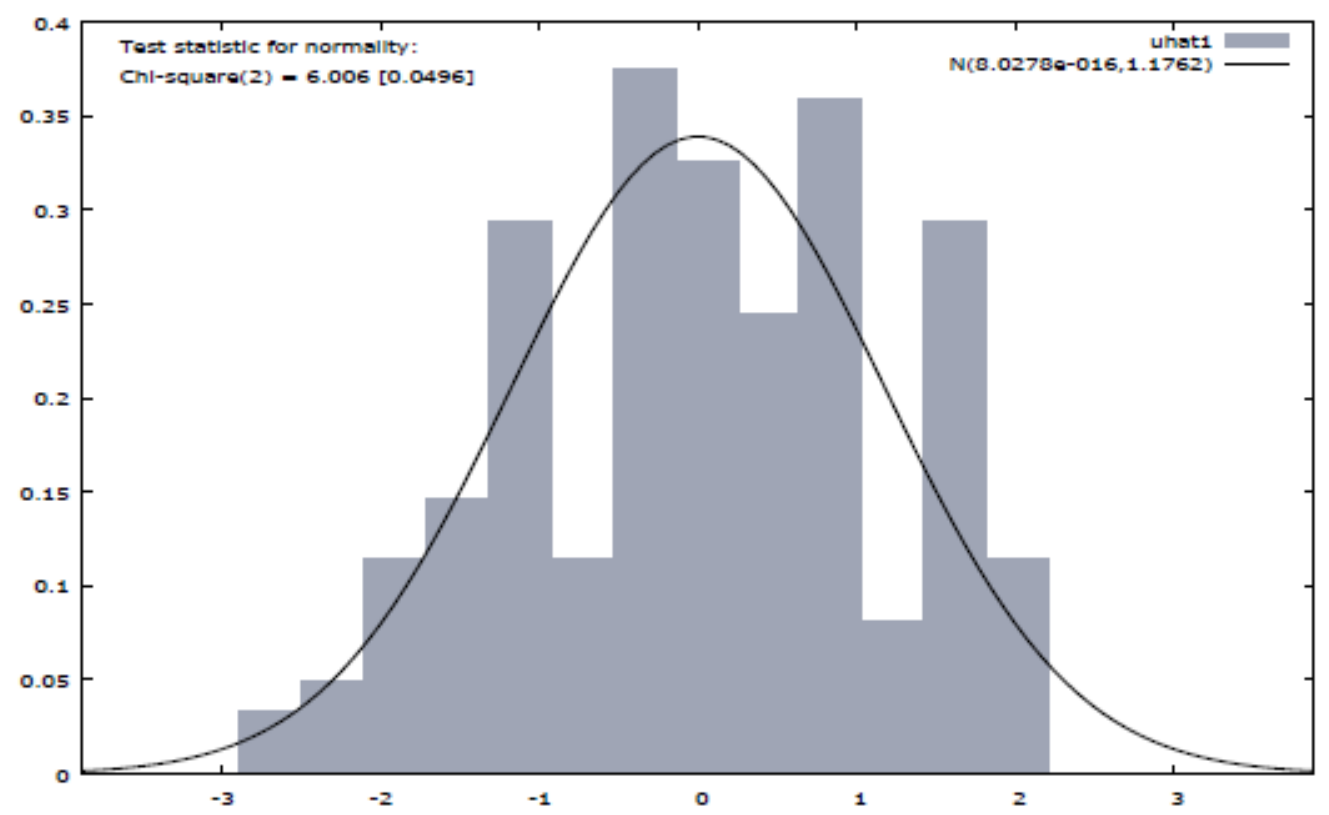

Source: Author

Figure 2 shows the residual normality test which shows that there is a normal distribution of data. Normal distribution means that the values are evenly distributed, ie this type of distribution shows that the mean values are the most frequent and as we move towards the ends the frequency of margins is lower.

\section{Discussion of results}

Descriptive statistics showed that approximately the same number of respondents buy white bread and pastries and wholemeal bread and pastries. Cereals and cereal products are bought to a lesser extent. They often buy white rice, while to a much lesser extent they buy integral rice. Respondents often buy confectionery products, for which the brand of the product is less important to them. This indicates that consumers in Serbia still do not take into account the health dimension of the product, because cereals and healthier cereal products (integral rice) are bought to a lesser extent.

The results of regression analysis (Model 1) showed that gender, as a demographic variable, is a significant factor influencing the purchase of cereal products, as shown by these studies (Mayer, 1978; Shepherd, 1999; De Jong, Ocke, Branderhorst \& Friele, 2003; Ares \& Gambaro, 2007; Sanlier \& Karakus, 2010). The financial situation (with/ without income) is also a significant factor influencing the purchase of cereal products. 
Consumers with income are more likely to buy cereal products. The more people receive a steady income and expect to continue to receive income, the more there are those who are in a position to make purchasing costs (Mayer, 1978, Simon \& Manohar, 2012; Herforth \& Ahmed, 2015). On the other hand results of regression showed that there is no statistically significant relationship between the level of education and the purchase of cereal products and between monthly income and the purchase of cereal products. There are no significant oscillations between respondents with different levels of education and the decision to buy cereal products, because all respondents more or less equally decide to buy them, since cereals and cereal products are necessary in the daily diet. Most of the respondents have lower incomes, so they are expected to consume cereal products, because they cannot afford a more varied diet. With the growth of income there is a change in consumption, primarily to a more varied diet that includes a higher proportion of animal proteins, fats and oils, while at the same time there is a decrease in demand for cereals, fruits and vegetables (Valin et al., 2014; Herforth \& Ahmed, 2015).

\section{Conclusion}

The research results show that:

- Hypothesis (H1) was confirmed because gender is a significant factor in the purchase of cereal products in the Republic of Serbia;

- Hypothesis (H2) is refuted because the level of education of consumers does not affect the purchase of cereal products in the Republic of Serbia;

- Hypothesis (H3) is confirmed because the financial situation of consumers affects the purchase of cereal products in the Republic of Serbia;

- Hypothesis (H4) is refuted because monthly receipts do not affect the purchase of cereal products in the Republic of Serbia.

The theoretical application of the results is reflected in the creation of profiles of consumers who buy cereal products in the Republic of Serbia and in other developing countries. Also, the theoretical application of the results is that the results can be the basis for a theoretical framework, ie. setting hypotheses in other studies.

The practical application of the results is reflected in the results that allow to effectively plan, implement and evaluate marketing strategies aimed at increasing use of cereal products in the Republic of Serbia, in the sense that it is based on gender and financial situation of consumers given that these demographic characteristics influence the purchasing decision when it comes to cereal products, that is, that the marketing strategy does not spend resources on consumer segmentation and everything that accompanies it according to monthly income and level of education.

The conducted research had certain limitations. The research was conducted through only one measurement, the obtained results were not confirmed as such once again, which affects the relevance of the obtained results. There are no data with which the 
obtained results could be compared, whether they confirm already existing results or can be considered as results indicating an exception.

The conducted research opens space for future research of the cereals market, which would include a number of factors (attitude towards health and healthy lifestyle, knowledge of food and eating habits, sociological and psychological factors, the influence of marketing factors before the promotion of cereals) then possible longitudinal and comparative research between cities, states. Research of this type would be of great importance for producers of cereal products, since the production and trade of cereals in the world tend to grow significantly, and cereals provide more than half of the total daily energy value of meals in the world. Therefore, ensuring an adequate supply of cereals is key to maintaining the food security of each country. Also, it is necessary to make certain efforts in educating consumers about the benefits of healthier products, and cereals are considered the healthiest food due to their properties.

\section{Conflict of interests}

The authors declare no conflict of interest.

\section{References}

1. Ali, J., Kapoor, S., \& Moorthy, J. (2010). Buying behaviour of consumers for food products in an emerging economy. British Food Journal, 112(2), 109-124. https:// doi.org/10.1108/00070701011018806

2. Alexandratos, N. (2006). World Agriculture: towards 2030/50, interim report. An FAO perspective. London, UK: Earthscan; Rome, Italy: FAO.

3. Ares, G., \& Gambaro, A. (2007). Influence of gender, age and motives underlying food choice on perceived healthiness and willingness to try functional foods. Appetite, 49, 148-158. https://doi.org/10.1016/j.appet.2007.01.006

4. Ares, G., Gimenez, A., \& Gambaro, A. (2008). Influence of nutritional knowledge on perceived healthiness and willingness to try functional foods. Appetite, 51(3), 663-668. https://doi.org/10.1016/j.appet.2008.05.061

5. Binkley, J.K., \& Eales, J.S. (2000). Demand for High Fiber and Low Fiber Cereals. A Selected Paper Presentation at the American Agricultural Economics Association Annual Meeting in Tampa, Florida, 1-23.

6. Charalampopoulos, D., Wang, R., Pandiella, S.S., \& Webb, C. (2002). Application of cereals and cereal components in functional foods: a review. International Journal of Food Microbiology, 79, 131-141. https://doi.org/10.1016/s0168$1605 *(02) 00187-3$

7. De Jong, N., Ocke, M.C., Branderhorst, H.A.C., \& Friele, R. (2003). Demographic and lifestyle characteristics of functional food consumers and dietary supplement users. British Journal of Nutrition, 89(2), 273-281. https://doi.org/10.1079/ BJN2002772 
8. EUFIC (2005). The Determinants of Food Choice. Retrieved from http://www. eufic.org/article/en/page/RARCHIVE/expid/review-food-choice/ (Jun 2, 2020).

9. Herforth, A., \& Ahmed, S. (2015). The food environment, its effects on dietary consumption, and potential for measurement within agriculture-nutrition interventions. Food Security, 7(3), 505-520. https://doi.org/10.1007/s12571-0150455-8

10. Kaur, I., \& Singh, S. (2014). Consumer Behavior of Purchase of Processed Cereal Food Products in Punjab. Journal of Business and Management, 16(2), 47-57.

11. Kamalaveni, D., \& Nirmala, L. (2000). Consumer behaviour in instant food products. Indian Journal of Marketing, 30(5-7), 12-18.

12. Kovljenić, M., \& Raletić-Jotanović, S. (2020). Food security issues in the former Yugoslav countries. Outlook on Agriculture, 20(10), 1-9. https:/doi. org/10.1177/0030727020930039

13. Lafiandra, D., Riccardi, G., \& Shewry, P.R. (2014). Improving cereal grain carbohydrates for diet and health. Journal of Cereal Science, 59, 312-326. https:// doi.org/10.1016/j.jcs.2014.01.001

14. Lahteenmaki, L. (2013).Claiming health in food products. Food Quality and Preference, 27, 196-201. https://doi.org/10.1016/j.foodqual.2012.03.006

15. Mayer, R.N. (1978). The Sociology of Consumption:Deriving New Social Indicators. Social Indicators Research, 5, 151-167. https://doi.org/10.1007/ BF00352926

16. Mitić, S., \& Gligorijević, M. (2015). Consumers' attitudes, knowledge and consumption of products with nutrition and health claims. Economics of Agriculture, 62(2), 335-352. https://doi.org/10.5937/ekoPolj1502335M

17. Raletić Jotanović, S., Sudarević, T., Katić, A., Kalinić, M., \& Kalinić, Č. (2016). Environmentally Responsible Purchasing - Analysis of the Ex - Yugoslavian republics. Applied Ecology and Environmental Research, 14(3), 559-572. https:// doi.org/ 10.15666/aeer/1403_559572

18. Raletić-Jotanović, S. (2017). Sustainable consumption in the Autonomous Province of Vojvodina. Novi Sad: Professional College of Management and Business Communication.

19. Radosavljević, M. (2010). Cereals - production, properties and organic food. Journal on Processing and Energy in Agriculture, 14(3), 131-134.

20. Roux, C., Le Couedic, P., Durand-Gasselin, S. \& Luquet, F.M. (2000). Consumption patterns and food attitudes of a sample of 657 low-income people in France. Food Policy, 25, 91-103. https://doi.org/10.1016/S0306-9192(99)00066-4

21. Roslow, S., Li, T. \& Nicholls, J.A.F. (2000). Impact of situational variables and demographic attributes in two seasons on purchase behaviour. European Journal of Marketing, 34(9/10), 1167-1180. https://doi.org/10.1108/03090560010342548 
22. Sanlier, N., \& Karakus, S. (2010). Evaluation of food purchasing behaviour of consumers from supermarkets. British Food Journal, 112, 140-150. https://doi. org/10.1108/00070701011018824

23. Sarwar, M.H., Sarwar, M.F., Sarwar, M., Qadri, N.A., \& Moghal, S. (2013). The importance of cereals (Poaceae: Gramineae) nutrition in human health: A review. Journal of Cereals and Oilseeds, 4(3), 32-35. https://doi.org/10.5897/JCO12.023

24. Sevak, L., Mangtani, P., McCormack, V., Bhakta, D., Kassam-Khamis, T., \& Silva, I. (2004). Validation of a food frequency questionnaire to assess macro- and micronutrient intakeamong South Asians in the United Kingdom. European Journal of Nutrition, 43, 160-168. https://doi.org/10.1007/s00394-004-0454-6

25. Simon S. \& Manohar M. (2012). An insight on consumer choice and marketing opportunities for breakfast- cereals. International Journal of Research in Commerce and Management, 3(12), 1-3.

26. Shepherd, R. (1999). Social determinants of food choice. Proceedings of the Nutrition Society, 58(4), 807-812. https://doi.org/10.1017/s0029665199001093

27. Urala, N., \& Lahteenmaki, L. (2007). Consumers' changing attitudes towards functional foods. Food Quality and Preference, 18(1), 1-12. https:/doi. org/10.1016/j.foodqual.2005.06.007

28. Valin, H., Sands, R. D., Mensbrugghe, D., Nelson, G.,C., Ahammad, H., Blanc, E., Bodirsky, B., Fujimori, S., Hasegawa, T., Havlik, P., Heyhoe, E., Kyle, P.,Croz, D., M., Paltsev, S., Rolinski, S., Tabeau, A., Meij1, H., Lampe, M., \& Willenbockel, D. (2014). The future of food demand: understanding differences in global economic models. Agricultural Economics, 45, 51-67. https://doi.org/10.1111/agec.12089

29. Vlahović, B. (2015). Market of agro-industrial products - special part. Novi Sad: University of Novi Sad, Faculty of Agriculture..

30. Worsely, A. (2003). The behavioural and demographic contexts of white bread consumption. British Food Journal, 105(10), 695-699. https://doi. org/10.1108/00070700310506245

31. Statistical Office of the Republic of Serbia (2020). Statistical yearbook. Retrieved from https://publikacije.stat.gov.rs/G2020/Pdf/G20202053.pdf (May 20, 2020).

32. FAOSTAT (2020). FAOSTAT Data - Crops. Retrieved from http://www.fao.org/ faostat/en/\#data/QC (Jun 2, 2020). 
